\title{
Surkhet
}

\section{Resolving ELT Challenges Through Critical Thinking Strategies}

- Rajan Kumar Kandel

\begin{abstract}
Overviewing the existing ELT challenges in Nepalese education, this article attempts to explore the challenges resulted from the age long conventional teacher-led, drilling, lecturing, note providing, and translation based teaching, and suggests to opt critical thinking (CT) strategies to solve the problems based on experiences and observations of the researcher for more than a decade. It tries to reflect how CT strategies help students in learning English inclusively in a co-operative and democratic class. A model lesson plan (along with pictures downloaded from the Internet) has also been appended to show how a teacher can introduce CT in ELT class in Nepal to overcome the challenges and lead the students to active and stress-free English learning. It also depicts positive consequences of the intervention (CT strategies) of the study resulted from action learning during the decade long practice and exploration of a teacher in his local context.
\end{abstract}

Key words: ELT challenges, hangover, critical thinking (CT) strategies, action research and action learning, government-aided and privately owned boarding schools.

\section{Background}

Teaching English in Nepal was started during Ranarchy from Darbar High School hiring English teachers. It was further expanded during post-democracy era when schools mushroomed in Nepal. Then, English was taken as a stimulating vehicle of an ideal culture and development. It was formally introduced in schools and colleges after the recommendation of National Educational System Plan (NESP) 1971. At that time, it was taught as a subject; rather than a language for communication. Neither language skills nor language aspects; but the content was solely focused. The trend exists even today after more than two scores of years

Nowadays, English is being introduced as a medium of instruction form primary schools to universities in Nepal. Thus, we can say that there has been paradigm shift in English language teaching in Nepal, because it has become a mean to achieve certain ends. Nevertheless, whether or not we should use it as a medium of instruction has already become a matter of debate and discussions. To comply with the new traditions, new methods, and new pedagogies have been 
searched; and courses have been prepared with a view to preparing learners compete globally. However, teachers who handle these courses have still hangovers of their past experiences which is why they encounter many challenges in their classes. These challenges have caused students' poor performance in English.

\section{English language teaching in Nepalese education}

In Nepal, English is taught as a compulsory subject from the first grade and this continues up to Bachelor Level in formal education. But the bitter truth is that the majority of the graduates feel frustrated when they have to ask for a cup of tea in English. Let's not talk those who fail in only English and therefore are deprived of being awarded the degree. This has made every English teacher in Nepal think over what we have been doing from ages. It is said that if the students do not learn/perform well, the teacher has not taught well. If this is to be taken for granted, we have not taught them in the way we should have (in many of the cases). All students/guardians/parents have owned considerable space, even the rights to blame to the teachers for the pitiable English language learning situation in Nepal.

\section{ELT challenges in Nepal}

The government itself does not formulate any policies to make education state-funded. There are two types of schools in the country, viz. the government aided community schools and the privately owned boarding schools. Children from the rich families receive the awaited English medium quality education and lead themselves to better careers, but the children from middle class families receive lower-quality English medium education and are denied better career opportunities, let alone the fate of those students from poor families who are compelled to receive Nepali medium education, which has created a huge gulf in the community (Shrestha, 2009). Although the policy of the government itself has made the level of English proficiency of the students from the poorer background inferior to those from well-off families, they have to attend the same School Leaving Certificate Examination popularly nicknamed as the irongate. Passing through this gate is mandatory to open up the window of higher education ahead.

The discrimination even does not end at this point. Those students have to face different entrance examinations to get admitted in the subjects of science, technologies, etc., and the test writers write the tests in English to which the students from the Nepali medium schools are less familiar with. English only hinders their performance resulting them to opt the subjects from humanities and education faculties. Their English does not improve in the over-crowded large classes there among the heterogeneous students (in terms of their linguistic, cultural, geographical, age, and sex related factors among others) either. It means the majority of our students studying B. Ed. are those students who are deprived of getting so-called English medium quality education in school level.

The weaknesses do not only go to the government. Teachers teaching English in school level use grammar translation method and chorus drills in the classroom though the textbooks are written according to CLT and task based learning (TBL) (Shrestha, 2009). There is mismatch between the theory and practice in the sense that even the trained teachers do not materialize the theories that have learned into practices. In fact, the teachers have been teaching the way their 
teachers taught them. That is to say, they all have been using grammar translation method very extensively. Furthermore, the number of students in the public institutions: be they in schools or campuses is very large. Sometimes, it exceeds hundreds of students in campus classes (especially in compulsory English). The classroom management and the school practices (to be fully based on the teacher and a single textbook) being continued are posing challenges in ELT. The overall challenges of ELT in Nepal are listed in the following points after a decade long experience, careful observation, and understanding derived from different discussions with the colleagues and students, trainings, seminars, conferences, and library study of the researcher:

- Lack of well trained teachers

- Gap between theory and practice (of the tutors)

- Mixed ability heterogeneous students (in terms of age, sex, linguistic knowledge, culture, etc.) in the classes

- Over-crowded large classes

- Poor physical facilities of the classrooms and the institutions

- Over- dependence on the teachers because of the assertive, dogmatic behavior of the students resulted by teacher/spoon fed instruction instead of student centered teaching

- Treating English as a subject rather than a language

- Lack of practice to discuss local context in English (nativization of English), i.e. dreaming for the communicative competence; rather than thinking about intercultural communicative ommunication

- Dual-education system in the school (government aided for the poor and privately owned boarding schools for the rich)

- Avoidance of the entrance examinations to opt English based on the aptitude and level of the students

- The way questions are asked in exams/examination system (carelessness of the test writers and examiners that has encouraged students to depend on guess papers and plagiarized bazar notes/ if test writers do not write the tests creatively and critically, let alone the creative and critical performance from the side of the students.)

- Absence of social use of English elsewhere outside the classroom (Both teachers and students do not feel comfortable in using English as a means of communication outside the classroom.)

- The practice of exam oriented instruction where the students ask the possible questions to be asked in the examination right from the beginning of the courses and teachers also try to focus on them

- The teachers are not well-paid and are compelled to search for additional jobs. As a result, they are less motivated to their professional development and do not prepare well and try their best to carry out classroom researches.

- Fear and anxiety of the students in English language classes

- Inability of the teachers and students to concentrate in teaching and learning And the must

- Unwillingness to think critically/ absence of critical thinking practice in teaching and learning 
The challenges mentioned above can be lessened (if not avoided) if we, language teachers try CT strategies in English classes. Students can activate their schemata, i.e. their prior knowledge about English and the whole world by critical thinking. CT leads students towards goal directed problem solving using their cognitive skills and strategies that guide them towards possibilities of desirable outcomes. In the paragraphs below, I discuss how CT strategies can be used to overcome the challenges in Nepalese ELT context.

\section{Critical thinking in Nepalese ELT context}

CT requires learners follow enquiry-based learning. It engages the learners while learning something. We can teach English to our students involving them in each and every activity we carry out in the classroom. Students exercise the freedom of answering questions and expressing their opinions during the class. CT can also build the habits of persuading others by rational arguments. We can change the class into thinking class to promote ELT getting the students do different activities using English in the class. Bowell and Kemp (2006) mention:

We do many things with language - state a fact, ask a question, tell someone to do something, insult someone, promise to do something, swear an oath, make a threat, tell a story, recite a poem, sing a song, say a character's line in a play, cheer on a football team. (p. 4)

This way, we can make the students do something by themselves even if the thing is small. CT urges the students to raise questions to explore the truth or knowledge. It does not lead them to take things for granted. As a result, they do not believe on dogmas, rather on the process of rational reasoning. We can develop the habit of critical thinking among our students through learning and training. We can encourage them to question, examine, create, solve, interpret, apply, and debate (rather than only memorizing) which, of course, minimize the void between the theory and our practices. In other words, $\mathrm{CT}$ aims at the higher order thinking from the side of the students instead of imitating and parroting the content to reflect it in the examination as the answer of the questions- those marked as VVI during instruction (because they are asked repeatedly) in their final paper and pencil tests.

CT develops the feel of ownership of their learning among the students. Ultimately, the learners become independent and life-long learners. They construct their knowledge themselves from their own rationality and experiences of the real world around them. They develop the habit of observing, noticing and locating the facts, guessing rationally, building assumptions and hypothesis, experiencing their opinions, arguing, analyzing critically, and creating. They enter into the realm of rationality and problem solving.

\section{The study: Rationale, objectives, data collection tools and procedure}

Being well-informed with the context of ELT in Nepal it was urgently realized to search the contextual strategies to be applied in ESL/EFL classes. The study was carried out to seek answers of the following questions:

- Why are the students poor even they are supposed to have achieved specified objectives?

- What are the alternative ways of teaching to improve their performance/ 
readiness in learning English?

- Will the students improve after being exposed to the critical thinking strategies?

- Who must have been responsible for the students' poor performance of English even they graduate?

- How can we motivate and encourage students to learn actively by themselves?

- What could be the potential result/ difference if critical thinking strategies are introduced in ELT classroom?

I tried an action in my regular compulsory English classes in collaboration with my students. I kept the records of the students for a week observing their interaction in the class among themselves in the groups and pairs and with me, the teacher. I analyzed the context using my own impression, judgment, reactions, feedback of colleagues, and students' opinions. During that period I used observation and oral questions as the tools to identify the real causes behind the poor performance of the students. The study was carried out in spite of the constraints of (a) the time (b) the incentive and (c) the expertise or professional support to get meaningfully engaged with research (Dornyei, 2007, p. 192) during my usual teaching. It was the result of an individual practice and reflection through the action in real classroom where the teacher himself has stood as the researcher. As an action research in nature, the main aim of this study was to observe the potential change in the students' performance in English had they been introduced CT strategies in their classrooms.

As action research, in the words of Cohen, Manion, and Morrison (2010), “...can be cast into two simple stages: a diagnostic stage in which the problems are analyzed and the hypotheses developed; and a therapeutic stage in which the hypotheses are tested by a consciously directed intervention or experiment in situ" (p. 304), this study broadly followed those two stages suggested by them. In the diagnostic stage the problems of ELT in our context were identified and the causes behind each problem were also listed and explained. In the therapeutic stage, CT strategies were practiced in the classroom unlike the teacher centered traditional strategies being used as usual and the outcomes were tested observationally and through oral questions again. This classroom research followed the common action research stages, viz. plan, teach/ act/intervene, observe, and reflect to be specific. I rightly followed the seven steps suggested by Nunan (2010, p. 19) in this study. At the initiation step I came up with the problem - the students passively listening and expecting everything from me, the teacher. I collected baseline data through observation and interview beside the study of ELT literature of Nepal, in preliminary investigation step. Then, I built the following hypotheses in the third step:

- Ho: There is no any relationship between our teaching and poor performance of our students in English.

- H1: Poor performance of our students is resulted because of our practice of conventional teaching methods.

- Ho: CT strategies cannot motivate, promote and improve students' proficiency in English over the conventional institutional practices.

- H1: CT strategies can motivate, promote and improve students' proficiency in 
English over the conventional institutional practices.

After that, I prepared for the intervention. CT strategies were introduced to motivate and encourage the students to relate any of the contents of the lesson to their own backgrounds and interests. After four weeks of teaching using CT strategies, I assessed my students and found much greater improvement in their performance and even in their motivation, in the evaluation step. It was found that complexities of language learning were minimized and student led interactions were enhanced. This improvement was discussed and circulated among the colleagues and the students in the dissemination step. I also prepared this paper as a part of dissemination. I have still been searching and investigating alternative methods of motivating students and improving their performance in the follow-up step. This is a never ending continuous cycle. The study can also be viewed through the eight step model of action research by McNiff (2002, p. 71) as cited in Cohen, Manion, and Morrison (2010, pp. 305-6), viz.

- Review your current practice

- Identify an aspect that you wish to improve

- Imagine a way forward in this

- Try it out

- Monitor and reflect on what happens

- Modify the plan in the light of what has been found, what has happened, and continue

- Evaluate the modified action

- Continue until you are satisfied with what aspect of your work (e.g. repeat the cycle)

Foreign or second language classroom was realized as a primary research site in applied linguistics (Dorneyei, 2007) in this study as well. Observation and self-reflection were used for research activity in teachers' professional life just like Dorneyei mentions, "Beside asking questions observing the world around us is the other basic human activity that all of us have been involved in since babyhood to learn and gain understanding." (ibid. p. 178).Observation and oral questionnaire to the students, thus, were used as the research tools in this research. It was geared up with the view that teaching is not only information transmission. The teachers' role in the class is not to spoon-feed the students, rather supporting their learning. In this sense, it is not only an action research but also action learning. The former is a methodological, systematic, and rigorous process of enquiry in which the results are disseminated for peer scrutiny, but the latter relies on personal observation and reflection (Norton, 2009, p. 31). Action learning involves taking action and reflecting upon the results to solve the problemsthat I have been doing since then. This study also helped to learn about the students' perceptions and feelings about their learning.

\section{Analysis and interpretation}

Qualitative analysis was used in this study because it is useful where:

- Little is known about the research area

- Richer understanding is sought

- More in-depth information is needed

- There are already existing sources such as diaries, students' assignments, video recordings, and reports.

(Norton, 2009, p. 116)

Very little was known about using CT in Nepalese ELT before the study was commenced. But I wanted to seek its deeper understanding. I 
needed the in-depth information of my students' beliefs of their learning. I had prepared the diaries of my teaching in the form of selfevaluation or reflection. I also had collected the first hand evidence of my students' assignments and reports. Because of these reasons, I used qualitative analysis in this study.

\section{Result}

Common strategies of critical thinking like think/pair/share (T/P/S), know/want to know/learn (K-W-L), what/so what/now what, $\mathrm{mix} /$ freeze/pair, quick write, pens in the middle, value line, directed reading activities (DRA), jigsaw, one stray/three stray, walk around/talk around, reciprocal teaching, save the last word for me, etc. were used to encourage even the hesitated students in language classrooms. Instructional language was rough-tuned and the teacher was even-handed in the class while using any of these activities among the students. It was to make the students autonomous in their learning. Students became accountable to what they $\mathrm{did} /$ did not do during the class activities.

These strategies of critical thinking are always very engaging and interactive. I tried many of these strategies in my classroom. I instructed them comprehensively reminding myself frequently to the points, viz. prepare, make sure you have the class's full attention, present the information more than once, be brief, illustrate with examples, and get feedback (Ur, 2010, pp. 16-17). Those points were found positive to me and the students. I found my students encouraged and interested during the classroom instruction with these activities. They felt happy to share their ideas among others. Each of the activities discussed above made the classroom lively and student centered. Students did not hesitate to ask questions with their friends when such activities were introduced. I tried to solve the problems with speaking by using group work, making the activities easy language, making a careful choice of topic and task to stimulate their interest, giving instruction or training in discussion skills, and keeping students speaking the target language (ibid., pp. 121-22) in the class. They did not only depend on their teachers and built the habit of thinking for the solutions/ answers of the questions/problems. It, ultimately, discouraged the exam only oriented instruction rather helped to achieve the objectives of the course/lesson creating an English environment at least in the classroom. Students were later found taking/using English even in the absence of teachers in and outside the classroom being equipped with such strategies that demand group/pair participation.

Similarly, I followed the ABC phases of critical thinking approach in English language teaching called anticipation, building knowledge and consolidation. At the stage of anticipation, I contextualized the content to use English and asked students what they already knew about it. I set the purpose of learning and clarified any misconceptions if they had about the topics under discussion. Students focused their attention on the topic and derived the context for understanding new ideas. In the second stage of building knowledge, I brought the learners into contact with new information, let them to query, find out and make sense of the idea under discussion. They identified the main points and made inferences about the materials. They made personal connections to the lesson or personalized the task or idea. Lastly, at the consolidation stage, students reflected on what they learnt, interpreted and shared experiences, summarized the main idea, and assessed their learning. They also thought of the solutions or 
remedies of the problematic parallel problems. A plan to teach a poem of B. Ed. 1st year following the strategies and phases of CT has also been appended herewith (Appendix I) consisting of some potential problems the teacher may have to face in the classroom so that $\mathrm{s} / \mathrm{he}$ can try earlier to overcome/neutralize such problems whenever they arise. Useful pictures downloaded from the Internet to teach the poem (Letter From Foreign Grave - by D. B. Gurung) have also been included with the plan.

\section{Discussions of findings}

CT strategies helped me to foster the good language learners' characteristics like- lower inhibition, encourage risk taking, build students' self-confidence, help students develop intrinsic motivation, promote cooperative learning, encourage students to use right brain processing, promote ambiguity tolerance, help students use their intuition, get students to make their mistakes work for them, and get students to set their goals (Brown, 2010, pp. 16-17) among the students of my classroom. Students thought of their learning rationally and did not afraid of committing mistakes while learning. CT promoted cooperation and positive competition among the students. They tried to learn even from their own mistakes and positive competition among their friends'. They claimed of their subjectivity to any issues under discussion rather than the fixed dogmas. CT strategies motivated, promoted, and improved students' proficiency in English over the conventional teaching methods. It showed that poor performance of our students was the result of our institutional practices.

CT strategies reduced the time and effort of the students' learning. It discouraged them to memorize the plagiarized bazar notes and the teachers' lecture notes only. Their learning also became goal oriented and they built themselves as the active learners fully accountable and responsible to their learning. None of the students in the class remained passive and mere recipients of the teacher's knowledge. CT intrinsically motivated them and grew them to solve problems and built intuition when needed. Their performance was dramatically improved because of their activies, immersion, into the problems and critical-creative thinking.

\section{Conclusion}

We can make use of strategies like using analogies and imaginations, promoting interaction among the students, allowing more than sufficient time for reflection in the class to promote critical thinking strategies in ELT classes. We can ask open ended questions to the students seeking varied subjective answers with considerable amount of time. Students may not answer instantly. Don't worry. They may have been thinking inside. Wait! The rice inside the pressure cooker may have been getting ready. It whistles to inform being ready when the students speak/write the reply. We must guide the students to apply the knowledge they learnt in different context with considerable modification. Rather than asking the problem just they are there, we can relate them to the real life situation of the students and we need to allow thinking practice and never expect for the fixed answers. We should not interrupt or overcorrect the students. It may discourage them. We should try our best to be as indirect as possible while correcting them. Fixed answers may be sought in other subjects but not in language teaching because our main goal behind teaching language is teaching the language itself not the subject matter alone.

Our current courses of TU (of B. Ed. and M. Ed.) have been changed reflecting the newly 
developed social, political, cultural, philosophical and academic changes home and abroad. They seek new student centered methods and nativization of English in different Nepalese cultures. They need a lot of reading and thinking from the parts of the teachers and students because the skill alone does not produce object/product without tools and the raw materials. Reading a lot, raising questions, and critical thinking both from the side of the teachers and students are desired.

\section{About the author \\ Mr. Kandel is Teaching Assistant of English Education at Surkhet Campus (Education) TU. He has been teaching Research Methodology for Language Education, English Language Teaching Methods, and Linguistics for more than five years. He is interested in research and research-specific practices. He has edited a couple of research and academic journals. He is Life Member of NELTA.}

\section{References}

Bowell, T., \& Kemp, G. (2006). Critical thinking: A concise guide. London and New York: Routledge.

Brown, H. D. (2010). English language teaching in the 'post-method' era: Toward better diagnosis, treatment, and assessment. In Richards, J. C., \& Renandya, W. A. (ed.).
Methodology in language teaching: An anthology of current practice. Cambridge: Cambridge University Press, pp. 9-18.

Cohen, L., Manion, L., \& Morrison, K. (2010).Research methods in education. London and New York. Routledge.

Dornyei, Z. (2007). Research methods in applied linguistics: Quantitative, qualitative and mixed methodologies. New York: Oxford University Press.

Nunan, D. (2010). Research methods in language learning (First South Asian edition). New Delhi: Cambridge University Press.

Norton, L. S. (2009). Action research in teaching and learning: A practical guide to conducting pedagogical research in universities. London and New York: Routledge.

Shrestha, P. N. (2008). An overview of ELT, EAP, and ESP in Nepal: Whose interest is served? In Krzanowsky, M. (ed.) EAP and ESP in developing countries: State of play vs actual needs and wants. Canterbury: IATEFL (ESP SIG), pp. 191210.

Ur, P. (2010). A course in language teaching: Practice and theory. Noida, U. P. India: Cambridge University Press. 


\section{Appendix I \\ A model lesson plan based on critical thinking strategies}

College: Surkhet Campus (Education)

Subject: C. English

Class: B. Ed. $1^{\text {st }}$ year

Time: 50 minutes

\section{Lesson Objectives}

At the end of this lesson the students will be enabled to:

- summarize the poem Letter From Foreign Grave.

- argue for and against fighting for others as Gorkhas.

- discuss on one's own enemies and the enemies of the masters/ employers (driving by rationality/heart vs. compulsion/ force).

- write a letter from the side of dead soldier's mother who still hopes that her son will return home.

\section{Teaching Materials}

Materials of daily use, Pictures of Gorkha soldiers fighting abroad for others(aggressively attacking the enemies in the fronts with the sharp Khukuris and the shout "Ayo Gorkhali", a soldier shot dead), New Generation English (the textbook - Letter From Foreign Grave - by D. B. Gurung)

\section{Teaching Learning Activities}

\begin{tabular}{|c|c|c|c|}
\hline Stages & Teacher & Students & Potential Problems \\
\hline $\begin{array}{l}\text { Anticipation } \\
\text { Phase (10 } \\
\text { minutes) } \\
\text { Strategies: } \\
\text { Think/ Pair/ } \\
\text { Share } \\
\text { (T/P/S) } \\
\text { Know/Want } \\
\text { to know/ } \\
\text { learn (K- W- } \\
\text { L) }\end{array}$ & $\begin{array}{l}\text { - Manages the class in the } \\
\text { orderly rows. } \\
\text { - Displays the pictures and } \\
\text { asks students to say a few } \\
\text { sentences about the } \\
\text { pictures. } \\
\text { - Selects } 15 \text { phrases from } \\
\text { the poem like; hundred } \\
\text { seas away, mundane } \\
\text { avarice, resting at peace, } \\
\text { ruined destiny, the unsung } \\
\text { song, bid farewell, eyes } \\
\text { welling up with tears, } \\
\text { abir-daubed brow, fronts, } \\
\text { piece of glowing lead, } \\
\text { scare to death, make up } \\
\text { for your milk, misery, lost } \\
\text { citizen of the world, } \\
\text { plunder and asks them to } \\
\text { use the phrases. } \\
\text { - Asks the students to think } \\
\text { up a story of a Gorkhali } \\
\text { soldier }\end{array}$ & $\begin{array}{l}\text { Follow the directions. } \\
\text { - Try their best to describe } \\
\text { the pictures. } \\
\text { - Share their opinions } \\
\text { about soldiers, their fate } \\
\text { and the force that lures } \\
\text { and compels them to be } \\
\text { involved as Gorkhas. } \\
\text { - Try to use these } \\
\text { phrases/words into their } \\
\text { own sentences. } \\
\text { Discuss with their friends } \\
\text { and teacher whenever } \\
\text { they feel difficulty. } \\
\text { They build up their story } \\
\text { and try to visualize the } \\
\text { sufferings of a soldier in } \\
\text { the fronts. }\end{array}$ & $\begin{array}{l}\text { - Some students find } \\
\text { no seats for them. } \\
\text { - Back benchers do } \\
\text { not participate/ } \\
\text { hesitate to } \\
\text { participate. } \\
\text { - Students find some } \\
\text { phrases/ words } \\
\text { very difficult. } \\
\text { - Some students } \\
\text { whose nearest ones } \\
\text { are soldiers or the } \\
\text { one affected by } \\
\text { war/ conflict may } \\
\text { feel like scratching } \\
\text { the healed wound. }\end{array}$ \\
\hline
\end{tabular}




\begin{tabular}{|c|c|c|c|}
\hline Stages & Teacher & Students & Potential Problems \\
\hline $\begin{array}{l}\text { Building } \\
\text { Knowledge } \\
\text { phase (30-35 } \\
\text { minutes) } \\
\text { Strategies } \\
\text { Directed } \\
\text { reading } \\
\text { activity } \\
\text { (DRA) } \\
\text { What/ So } \\
\text { what/ Now } \\
\text { what }\end{array}$ & 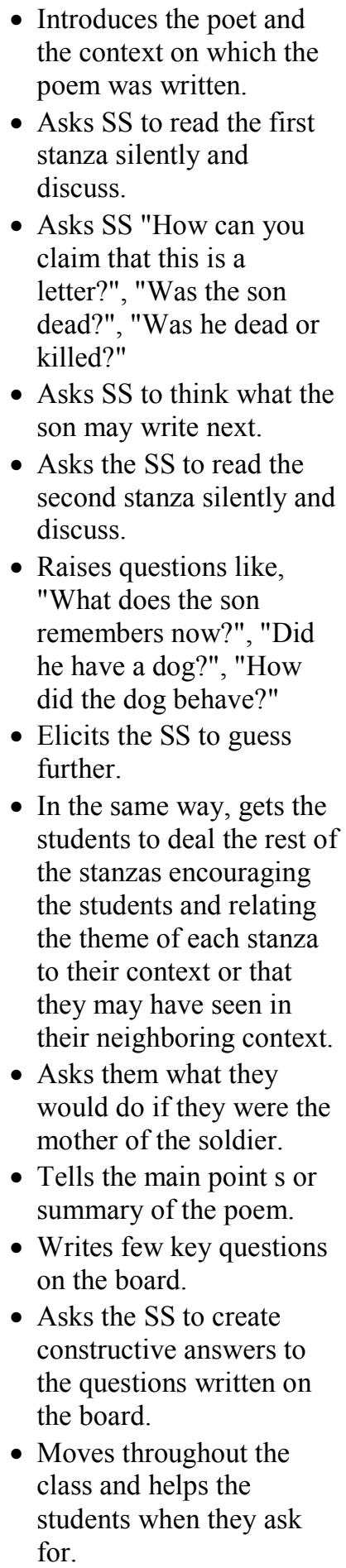 & $\begin{array}{l}\text { - Listen to the teacher } \\
\text { attentively. } \\
\text { - Read the first stanza and } \\
\text { discuss with their friends. } \\
\text { - Reply the teacher. } \\
\text { - Listen to their friends } \\
\text { replying their teacher and } \\
\text { try to notice the points } \\
\text { that they may have } \\
\text { missed. } \\
\text { - Say what they think. } \\
\text { - Read and ask if some } \\
\text { words/phrases are } \\
\text { difficult. } \\
\text { - They discuss among their } \\
\text { friends and try to reply } \\
\text { the teacher. They try to } \\
\text { personalize the situation } \\
\text { into their context. } \\
\text { - Activating themselves, } \\
\text { discuss and come up with } \\
\text { different ideas. } \\
\text { - Listen to their friends } \\
\text { carefully and add to them. } \\
\text { - They try thinking } \\
\text { creatively and participate } \\
\text { in the discussion after } \\
\text { they finish reading the } \\
\text { poem once again. } \\
\text { They try to pretend } \\
\text { themselves as the mother, } \\
\text { father, brother, sister of } \\
\text { the soldier. } \\
\text { answeate constructive } \\
\text { compare what they think } \\
\text { written on the board. } \\
\text { and the teacher says. } \\
\text { and to the teacher and } \\
\text { - }\end{array}$ & $\begin{array}{l}\text { - Few of the students } \\
\text { do not understand } \\
\text { the teacher. } \\
\text { - SS may not guess } \\
\text { meanings of words. } \\
\text { - Some of the SS } \\
\text { may have forgotten } \\
\text { their textbooks. } \\
\text { - Some of the SS } \\
\text { may not listen to } \\
\text { others/ make noise. } \\
\text { - Teacher may miss } \\
\text { to involve the } \\
\text { hesitated SS. } \\
\text { - Some SS do not } \\
\text { listen to their } \\
\text { friends. } \\
\text { - Some SS do not try } \\
\text { to put forward their } \\
\text { ideas. } \\
\text { - SS may feel tired to } \\
\text { participate. } \\
\text { - They may not be } \\
\text { involved in } \\
\text { thinking creatively. } \\
\text { - SS may feel } \\
\text { worried/ } \\
\text { disappointed when } \\
\text { they think of being } \\
\text { the nearest one of } \\
\text { the soldier killed. } \\
\text { - Some of the SS } \\
\text { may only write the } \\
\text { questions on their } \\
\text { notes. }\end{array}$ \\
\hline
\end{tabular}




\begin{tabular}{|c|c|c|c|}
\hline Stages & Teacher & Students & Potential Problems \\
\hline $\begin{array}{l}\text { Consolidatio } \\
\text { n Phase (10- } \\
15 \text { minutes) } \\
\text { Strategies: } \\
\text { T/P/S, Walk } \\
\text { around /Talk } \\
\text { around, } \\
\text { Quick write }\end{array}$ & $\begin{array}{l}\text { - Divides the SS into three } \\
\text { groups. } \\
\text { - Says them to list few } \\
\text { important vocabularies } \\
\text { and points of the poem. } \\
\text { - Asks each group to share } \\
\text { their points. } \\
\text { - Enlists the vocabularies } \\
\text { and points from the class. } \\
\text { - Elicits them to argue for } \\
\text { and against "Fighting for } \\
\text { others as Gorkhas" and } \\
\text { then on "Fighting by heart } \\
\text { and fighting by force". } \\
\text { - Says SS to jot down few } \\
\text { points they put forward } \\
\text { after discussion in their } \\
\text { respective groups, come } \\
\text { front and read it out. } \\
\text { - Assigns SS to write an } \\
\text { argumentative essay on } \\
\text { 'The Fate of Gorkhas' } \\
\text { - Assigns SS to write a } \\
\text { letter to the killed son } \\
\text { being his hopeful mother }\end{array}$ & $\begin{array}{l}\text { - Be members of the groups. } \\
\text { - kork in group and list the } \\
\text { key vocabularies and the } \\
\text { points of the poem. } \\
\text { - Reflect the work of their } \\
\text { groups. } \\
\text { - One group speaks for the } \\
\text { motion and another } \\
\text { against it and the third } \\
\text { group tries to negotiate } \\
\text { being neutral. } \\
\text { - Each group leader justifies } \\
\text { and illustrates the reasons } \\
\text { logically from the front. } \\
\text { - Write quickly. } \\
\text { - Listen to the teacher and } \\
\text { map their mind for the } \\
\text { task. } \\
\text { Imagine being the mother } \\
\text { of the son killed in the } \\
\text { foreign grave still waiting } \\
\text { her son's safe return and } \\
\text { overflow their feelings } \\
\text { and prepare for expressing } \\
\text { them in the letter. }\end{array}$ & $\begin{array}{l}\text { - Some SS may like } \\
\text { to change the } \\
\text { group. } \\
\text { - Some SS may just } \\
\text { look at their friends } \\
\text { enlisting. } \\
\text { - SS may make noise } \\
\text { in the class. } \\
\text { - The argument may } \\
\text { proceed } \\
\text { aggressively. } \\
\text { - Teacher may forget } \\
\text { to calm down the } \\
\text { SS at the } \\
\text { back/corners. } \\
\text { - Some SS may not } \\
\text { record the } \\
\text { assignments } \\
\text { claiming that they } \\
\text { can do them well. }\end{array}$ \\
\hline
\end{tabular}
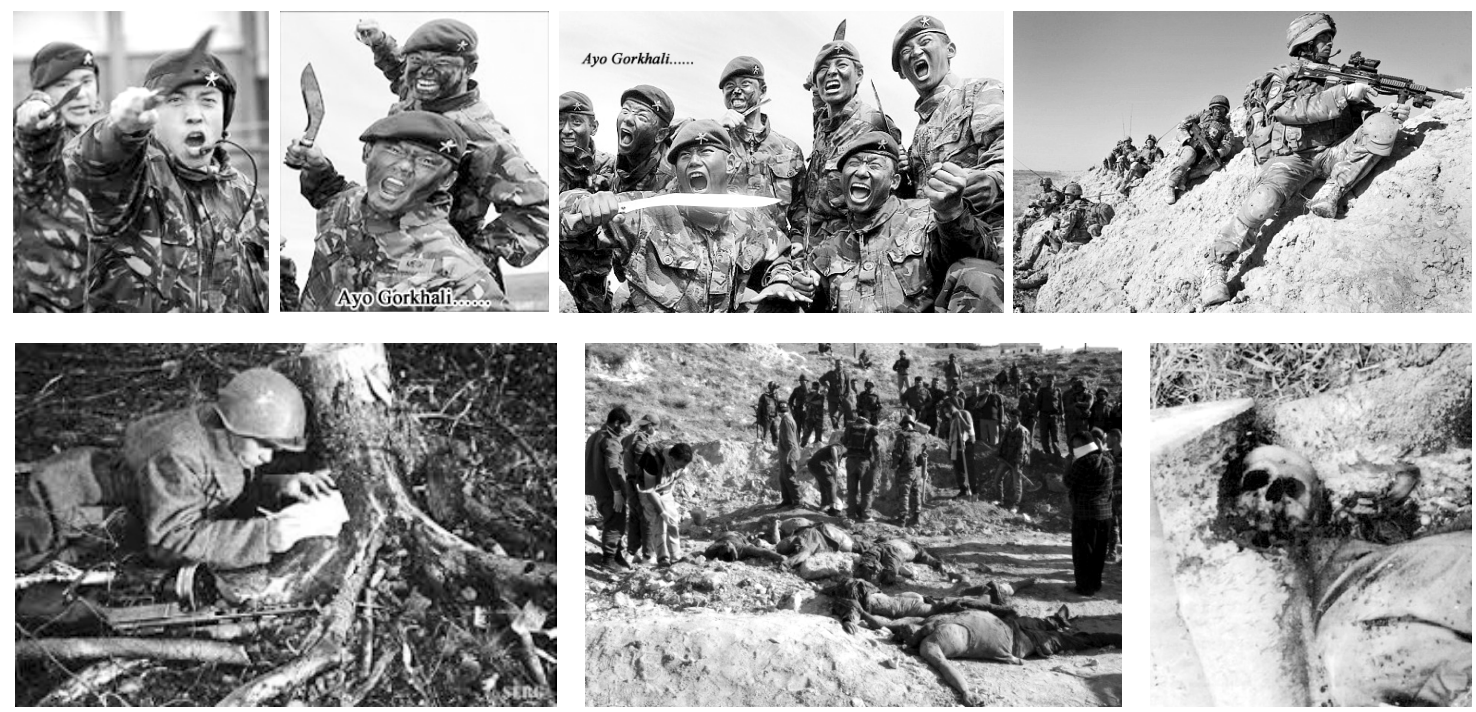

All the photos are downloaded from the Internet through Google search engine. 